\title{
Factors Affecting Dental Nurses Productivity in Running Community-Based Health Effort Coaching
}

\author{
Bambang Sutomo ${ }^{1, *}$, Antono Suryoputro ${ }^{2}$, Priyadi Nugroho ${ }^{3}$, Sadimin ${ }^{4}$ \\ ${ }^{1}$ Poltekkes Kemenkes Semarang, Indonesia. \\ ${ }^{2}$ Universitas Diponegoro, Semarsang, Indonesia \\ ${ }^{3}$ FKM Universitas Diponegoro, Semarang, Indonesia \\ ${ }^{4}$ Poltekkes Kemenkes Semarang, Indonesia
}

*Corresponding Author: Bambang Sutomo, Politeknik Kesehatan, Kemenkes Semarang, Jl. Tirto Agung Pedalangan, Banyumanik, Indonesia. Email: bambangsutomo20@yahoo.co.id

\begin{abstract}
Background: Teeth care for Indonesian people is run through several efforts including the involvement of community development program known as Usaha Kesehatan Bersumberdaya Masyarakat (UKBM) or Community-Based Health Effort. However, the progress remains slow.
\end{abstract}

The Objective: The purpose of this study to determine the effect of age, promotion, responsibility, quality control, and incentives in determining the productivity of dental nurses at the health center when coaching community in Semarang District, Indonesia.

Method: The study was conducted by quantitative explanatory research with a cross-sectional approach. Population and sample all 35 dental nurses who work at the health center in the district of Semarang The data were analyzed with chi-square correlation test and logistic regression.

Result: The results showed only the quality of supervision ( $p$-value $=0.002$ ) that is significantly correlated with the productivity of dental nurses when coaching community in Semarang District, Indonesia.

Conclusion: It is suggested that the head of the health center provides recommendations on the task of moving work and learning as well as conducting periodical reviews on the reward.

Keywords: Dental nurse, Community-Based Health Effort, productivity, coaching

\section{INTRODUCTION}

Usaha Kesehatan Bersumberdaya Masyarakat (UKBM) or Community-Based Health Effort is an effort and a form of direct participation of the community. The law of Republic Indonesia on health states that every person is obliged to come to realize, maintain, and improve public health the highest. The existence of this obligation shows that health development is not only the responsibility of government but also the public.

As a form of realization of fostering community participation in dental care, dental health professionals who are entirely responsible for coaching are dental nurses.

The fact is, coaching done by a dental nurse to the public is still not optimal. Low coverage in the form of coaching by officers on community- based activities shows that dental health worker productivity remains low. Labor productivity is a result of the work of an employee (Almigo, 2004). Work productivity is a measure of the performance in determining how the effort to achieve high productivity in an organization (Soedarmayanti, 2001).

The low productivity of dental nurses might due to they rarely get a warning from the head of the health center supervisor. This was according to the results of preliminary studies by interviewing 15 dental nurses who work at the health center in the district of Semarang where 11 people $(73.3 \%)$ claimed as never being reprimanded for the low productivity. The rest of 4 dental nurses (26.7\%) felt indifferent and not trying to boost small productivity. Besides, 12 people $(80 \%)$ feel not to receive additional incentives when running coaching development 
activities. Also, 15 people were also experiencing problems in promotions.

By looking at the circumstances that occurred in the field, besides issues related to productivity, also found problems relating to wages or salary, incentives or rewards, promotion opportunities, responsibilities, and quality control.

\section{Materials AND Methods}

This research was non-experimental design with the quantitative explanatory study. Researchers wanted to see the relationship between the age, promotion, responsibility, quality control and employee benefits with productivity in the dental nurse at the health. The population was 35 dental nurses who worked at the health center in the district of Semarang. The bivariate analysis was performed by bivariate correlation with the aim to determine whether there is a relationship between each variable. The correlation test applied Chi-Square with a 95\% confidence level $(\alpha=0.05)$. $\mathrm{H}_{\mathrm{a}}$ will be accepted if the value of $p<0.05$.

\section{RESUlTS AND DISCUSSIONS}

\subsection{Result}

The result of the calculation of average achievement of productivity obtained a total of $84.2 \%$. As the target is $100 \%$ while the achievement is less than $100 \%$, then it is in the category of less productive. The age distribution showed that older age group was $54.3 \%$ and the younger age group was 16 people (45.7\%). Chi-
Square test with a 95\% confidence level $(\alpha=$ $0.05)$, obtained $p$-value $=0.478$. Since the $p$ value $>\alpha$ then $\mathrm{H}_{0}$ is accepted and $\mathrm{H}_{\mathrm{a}}$ is rejected indicating there is no significant relationship between age and dental nurses' productivity. The presumption of respondents regarding promotional opportunities is still low. Only $48.1 \%$ respondents believe that they are promoted to the higher level if they have succeeded developing Community-Based Health Effort. Chi-Square test with a $95 \%$ confidence level $(\alpha=0.05)$ obtained $p$-value $=0.632$. Since the $\mathrm{p}$-value $>\alpha$ then $\mathrm{H}_{0}$ is accepted and $\mathrm{H}_{\mathrm{a}}$ is rejected denoting there is no correlation between promotional opportunities with dental nurses' productivity. Respondents' assumption about responsibility to lower categories was $45.7 \%$ smaller to those who assume that they belong to responsibilities of the high category which was $54.3 \%$. Chi-Square test with a $95 \%$ confidence level $(\alpha=0.05)$ obtained $\mathrm{p}$-value $=0.983$ showing there is no significant relationship between responsibility to dental nurses' productivity. In supervision, the presumption of respondents regarding that the quality of supervision was low reached $48.6 \%$, and the quality control of high category was $51.4 \%$. Chi-Square test with a $95 \%$ confidence level $(\alpha$ $=0.05$ ) obtained $\mathrm{p}$-value $=0.002$ indicating there is a significant relationship between the qualities of supervision with dental nurses' productivity in Semarang regency.

To sum up, the result of hypothesis testing is summarized below:

Table. Hypothesis testing summary

\begin{tabular}{|c|c|c|c|c|}
\hline No. & Independent variable & Dependent variable & $p$-value & Description \\
\hline 1 & Age & \multirow[t]{5}{*}{ productivity } & 0,478 & No relationship \\
\hline 2 & Promotion & & 0.632 & No relation \\
\hline 3 & Responsibilities & & .983 & No relationship \\
\hline 4 & Incentives & & 0,656 & No relationship \\
\hline 5 & Quality control & & 0.002 & There is a relationship \\
\hline
\end{tabular}

\subsection{Discussion}

The results showed that there was no relationship between age and productivity. This is not consistent with the theory raised by Robins, who said that the performance of workers would decline with age. However, another study shows that generation has a positive and significant impact on employee's productivity (Pajar, 2008).

The dental nurses in Semarang district have the characteristic features which adopt the opposite where productivity will occur when a person's age is already matured and leads to the older.
With the increasing age, a person's work experience will also increase. The more experience a person, the more the ability to be able to solve problems and produce more work productive. There is a possibility of the addition of a worker age will only increase the positive aspects. The existence of a more extended work experience will improve the ability to analyze or assess the world of work that can affect the performance increase. (Robbins dan Judge, 2003).

Aspects of promotional opportunities perceived by the dental nurse are not related to 
productivity. It can be seen from the perspective of promotion opportunities are still low is regarding the lack of recognition by providing a point in a more substantial number of credits for fostering UKBM. Given this reality makes dental nurses are not motivated to improve guidance UKBM because they did not get enough rewards points through credit numbers. Their expectations with the end of credit rate are to gain promotion to the higher dental nurse working position. However, because the respondents felt appreciation was not optimal, then it decreased the productivity.

Also, the results also indicate the existence of job offers for a better promotion because it is fostering UKBM. This aspect is as positive, but because it is not supported by other elements followed by the recommendation to be able to move to the higher level, the process of development promotion is also not realized. So, in the end, promotional opportunities that exist in the dental nurse has no impact on work productivity.

Every employee has craved sale because with the transaction is seen as a reward for a person's success by showing a high performance in fulfilling obligations in employment and current occupation as well as recognition of the capabilities and the corresponding potential to occupy a more senior position in the organizational unit (Siagian, 2009).

The results of research are not by previous studies conducting in another province of Indonesia stating there is a definite and significant relationship between the promotional aspects of working with productivity (Almigo, 2004).

The results of the study did show that the aspect of responsibility already exists, but the shape of the duties of dental nurses has not been realized in implementation. A clear understanding of who is responsible for what, with no gaps in between some accountability is not fully understood yet. Measuring how far employers assume the liability to achieve the objectives must be implemented (Handoko and Hani, 1995) additionally, the responsibilities relating to the implementation of productivity in development activities outside of the building must be stated.

Or on the other hand, the dental nurses may already know $t$ the kind of responsibility that should be done but it is not conducted. This is consistent with human nature as the theory presented by Douglas Mc Gregor in so-called theory $\mathrm{X} \& \mathrm{Y}$. According to the theory $\mathrm{X}$, employees, do not like the job, and as much as possible try to avoid it; employees will avoid responsibilities and seek formal orders when possible (Robins and Judge, 2003). This theory shows that in a person there are properties to be able to avoid responsibility to seek some efforts including waiting and searching for a formal order to perform obligations. So that what happened in the district of Semarang, chances are they already know their responsibility as a dental nurse, but not to implement it. This theory also justifies why close supervision becomes the only variable that positively influences the productivity of the dental nurses. The results indicate that the rewards as retribution for dental nurses in the form of direct compensation, and includes salary or wages in the way of incentives for dental nurses in Semarang district which fall into the category of low contention. Statistical test results also showed no relationship between the remuneration with productivity dental nurse working in coaching UKBM in Semarang regency. The results showed that regarding compensation in the form of salary, respondents felt that the amount of pay and the period of salary increases have been in line with expectations. Meanwhile, in the granting of incentive compensation in the form there is also a fundamental rule that is used as a guideline for the distribution of incentives.

So from the research results show that there are fundamental rules that are used as guidelines for the distribution of incentives, but this practice is not executed. As delivered Hasibuan (2003) on the relationship between compensation and productivity- if productivity is right, the benefit will be even more significant. Conversely, if the work productivity is weak, then a small payment will occur (Hasibuan, 2003).

\section{CONClusion}

The productivity of dental nurse working in Semarang District in the category of coaching is not productive yet with the distribution of the spread of $69 \%$ out of $100 \%$ targeted. The factor associated with productivities of working dental nurse in the coaching of Usaha Kesehatan Bersumberdaya Masyarakat (UKBM) or Community-Based Health Effort in Semarang district is the quality of supervision. This way, the model of an efficient supervision should be formulated to achieve the objective. Since the 
dental nurses are white collar employees, a method of monitoring should be appropriate to the one applied to the knowledge workers.

\section{REFERENCES}

[1] Almigo,N. Hubungan Antara Kepuasan Kerja dengan Produktivitas Kerja Karyawan (The Relation Between Job Satisfaction and The Employees Work Productivity). Jurnal PSYCHE Fakultas Psikologi Universitas Bina Darma Palembang. Palembang. 2004

[2] Handoko, T. Hani. Manajemen. Edisi II. Cetakan keenam, BPFE, Yogyakarta.1995

[3] Hasibuan, M. Manajemen Sumber Daya Manusia. Bumi Aksara. Jakarta. . 2003
[4] Pajar. Analisis Faktor-Faktor Yang Mempengaruhi Produktivitas Kerja Karyawan Bagian Keperawatan Pada Rumah Sakit PKU Muhammadiyah Surakarta, Fakultas Ekonomi Universitas Muhammadiyah Surakarta. 2008.

[5] Siagian, SP. Manajemen Sumber Daya Manusia. Bumi Aksara. Jakarta. 2009

[6] Soedarmayanti. Sumber Daya Manusia Dan Produktivitas Kerja. Mandar Maju. Bandung. 2001

[7] Robbins, Stephen P. - Timothy A.Judge, 2003, Organizational Behavior. Prentice Hall.

Citation: Bambang Sutomo, Antono Suryoputro, Priyadi Nugroho, Sadimin. Factors Affecting Dental Nurses Productivity in Running Community-Based Health Effort Coaching, ARC Journal of Nursing and Healthcare. 2017; 3(4): 1-4. doi: dx.doi.org/ 10.20431/2455-4324.0304001.

Copyright: (c) 2017 Authors. This is an open-access article distributed under the terms of the Creative Commons Attribution License, which permits unrestricted use, distribution, and reproduction in any medium, provided the original author and source are credited. 